\title{
Motive of cossack mode of life in the works of Sandzhi Balykov (on the material of the novel "Zalamdzha")
}

\section{Motivo del modo de vida cossack en las obras de Sandzhi Balykov (sobre el material de la novela "Zalamdzha")}

\author{
Ochirova Nyudlya Chetyrovna \\ Associate Professor, Kalmyk State University named after B.B.Gorodovikov, Republic of \\ Kalmykia, Elista, Pushkin. \\ ORCID: https://orcid.org/0000-0002-5582-474X
}

\section{Sharapova Nina Nikolaevna}

Associate Professor, Kalmyk State University named after B.B.Gorodovikov, Republic of

Kalmykia, Elista, Pushkin.

ORCID: https://orcid.org/0000-0002-0555-2360

\section{Davaeva Arina Boovaevna}

Graduate student, Kalmyk State University named after B.B.Gorodovikov, Republic of Kalmykia,

Elista, Pushkin.

ORCID: https://orcid.org/0000-0002-2344-7820

Dyusamalieva Mariya Anatoljevna

Graduate student, Kalmyk State University named after B.B.Gorodovikov, Republic of Kalmykia, Elista, Pushkin.

ORCID: https://orcid.org/0000-0001-6332-983X

\section{Ivasenko Mariya Aleksandrovna}

Graduate student, Kalmyk State University named after B.B.Gorodovikov, Republic of Kalmykia, Elista, Pushkin.

ORCID: https://orcid.org/0000-0002-8309-8300

*Correspondence

Email: ivannovadremova29@gmail.com
Cite as:

Ochirova, N., Sharapova, N., Davaeva, A., Dyusamalieva, M., Ivasenko, M. (2021). Motive of cossack mode of life in the works of Sandzhi Balykov (on the material of the novel "Zalamdzha"). Propósitos y Representaciones, 9 (SPE1), e912. Doi: http://dx.doi.org/10.20511/pyr2021.v9nSPE1.912 


\section{Summary}

The article analyzes the motive of the Cossack mode of life in the works of an outstanding representative of Kalmyk literary Diaspora, a publicist, a journalist, a public figure, an officer of the Cossack regiment of the Don army, a participant of the Civil War in Russia, a bearer of living history belonging to the first wave of Russian emigration. As a result of an objective study of definite specific features of the traditional way of life of Don Kalmyks-Cossacks in the works of S.Balykov, the pattern of the writer's appeal to the realities of the traditional Cossack mode of life of Don Kalmyks is examined, the principles of its representation on the material of the novel "Zalamdzha" are revealed, a variety of phenomena related to the the most important concepts of everyday life, mode of life and foundations of the Don Cossacks-Kalmyks are analyzed. The realities of the national mode of life and the foundations of Kalmyk Cossacks are fully reflected in the writer's works. The consideration of preceding events having made an impact on the writer's works and his interaction with common-literary process gives us reasons to presume the extreme importance of historical cultural phenomena, the reflection of which has become the result of $\mathrm{S}$. Balykov's immediate flashbacks.

Keywords: literature of Kalmyk Diaspora, Sandzhi Balykov, novel "Zalamdzha”, Don KalmyksCossacks, motive of Cossack mode of life.

\section{Resumen}

El artículo analiza el motivo del modo de vida cosaco en las obras de un destacado representante de la diáspora literaria de Kalmyk, un publicista, un periodista, una figura pública, un oficial del regimiento cosaco del ejército del Don, un participante de la Guerra Civil. en Rusia, portador de una historia viva perteneciente a la primera ola de emigración rusa. Como resultado de un estudio objetivo de las características específicas definidas de la forma de vida tradicional de Don Kalmyks-Cossacks en las obras de S. Balykov, el patrón de apelación del escritor a las realidades del modo de vida tradicional cosaco de Don Kalmyks es examinado, se revelan los principios de su representación sobre el material de la novela "Zalamdzha", se analizan una variedad de fenómenos relacionados con los conceptos más importantes de la vida cotidiana, modo de vida y fundamentos de los Don Cossacks-Kalmyks. Las realidades del modo de vida nacional y los cimientos de los cosacos de Kalmyk se reflejan plenamente en las obras del escritor. La consideración de eventos precedentes que han tenido un impacto en la obra del escritor y su interacción con el proceso literario común nos da razones para presumir la extrema importancia de los fenómenos culturales históricos, cuyo reflejo se ha convertido en el resultado de los flashbacks inmediatos de S. Balykov.

Palabras clave: literatura de la diáspora de Kalmyk, Sandzhi Balykov, novela “Zalamdzha", Don Kalmyks-Cossacks, motivo del modo de vida cosaco.

\section{Introducción}

The revealing and study of characteristics of the traditional way of life of sub-ethnic groups are the most important components in the preservation and development of the national culture including literary art. The study of Sandzhi Balykov's (1894-1943) works is due to insufficient scientific status in Kalmykology and need for a more detailed research of Cossack motives in the writings of an outstanding representative of Kalmyk literary Diaspora, a publicist, a journalist, a public figure, an officer of the Cossack regiment of the Don army, a participant of the Civil War in Russia, a bearer of living history belonging to the first wave of Russian emigration.

The literary works of Sandzhi Balykov date back to the beginning of the Civil War in Russia. He was an exceptionally talented person who had great authority both in the field of sociopolitical activity with Kalmyk and Cossack clerisy in exile and in the field of literature (Balykov, 
2013). The years of emigration 1920-1930-s have become one of the most rewarding periods of his journalistic, literary and cultural activity.

Insufficient coverage of the topic is to a great extent connected with the fact that scientists have relatively recently embarked on a study of the works of the Kalmyk emigrant writer S.B. Balykov that came to light among native readers only in the 1990-2000-s.

Furthermore, the significance of the work under discussion is caused both by the current situation of the Cossacks in our country, the revival of which was largely intensified at the close of XX-th - beginning of XXI-st centuries, and by an ever increasing interest of scientists and members of general public in the most serious areas of concern of the Cossack's development. At the present time the study of the history of the development of ethnic and social groups of population of the south of Russia, including Kalmyk ethnic group, particularly foregrounds the preferred issue (Ochirova, 2019).

The scientific novelty of the study is determined by a comprehensive approach to the analysis of the most important ideas of Cossack life, their mode of life, and the foundations of Don Kalmyks in S. Balykov's works. The aim of the research consists in an objective study of definite specific features of the traditional way of life of Don Kalmyks-Cossacks in the writings of S. Balykov. The aim of the research predetermined the solving of the following objectives: to consider the pattern of S. Balykov's appeal to the realities of the traditional Cossack mode of life of Don Kalmyks and to reveal the principles of its representation in his writings, to analyze a variety of phenomena related to the the most important concepts of everyday life, mode of life and foundations of the Don Cossacks-Kalmyks.

\section{Methods}

The main methodological research principles are historical-literary, comparative-typological, systematic and biographical methods of analysis and a method of literary interpretation, which give an opportunity to solve the tasks set in the work. Also, the project takes into account historical principle since the object is being considered within a definite historical context. This manifested in their interpretation of the "multicultural" writer's creative method, reliving their childhood years, and introducing the reader to the history of their homeland using new literary devices (Gilfanova et al, 2020). The scientific equity is expressed in attracting existing sources on the issues and systematic approach to the analyzed material.

It stands to reason that the study of the history of the development of contemporary Kalmyk literature will not be objective without reference to the literary activity of Kalmyk clerisy who found themselves in exile as a result of a series of socio-political events in the country. In recent decades there has been a clear interest of researchers in this issue.

The writer's works are on a reasonable basis the object of attention of Kalmyk and domestic researchers, particularly literary scholars, linguists, historians, sociologists, etc. A series of contributions in recent decades is dedicated to the issues of literary and social activity of S.B. Balykov - Sh.N. Balinov (Balinov, 1976), A. Bormanzhinov (Bormanzhinov, 1998; Bormanzhinov, 2004), R.A. Dzhambinova (Dzhambinova, 2003), B.A. Bicheev (Bicheev, 1991), to the history of Kalmyk emigration - A.T. Goryaev, I.V. Borisenko (Goryaev \& Borisenko, 1998), P.E. Alekseeva (Alekseeva, 2010; Alekseeva, 1995; Alekseeva, 2006), D.A. Sharmandzhiev (Sharmandzhiev, 2013), E-B.M. Guchinova (Guchinova, 2004), A.T. Bayanova (Bayanova, 2013), to some issues of preservation of national traditions - D.Yu. Topalova (Topalova, 2015), to rites and ritual folklore - T.G. Basangova (Basangova, 2015), to Don dialectisms and South Russian lexicon in the writer's prose of A.A. Burykin (Burykin, 2006) and others. 
In modern literary criticism the investigations of K.G. Ivanov (Ivanov, 2014), V.V. Kondratjeva (Kondratjeva, \& Larionova, 2015), M.Ch. Larionova (Larionova, 2018) are devoted to the Cossack theme in the works of Russian writers.

Nowadays in the Russian historiography there are no works devoted to the analysis of a motive of Cossack mode of life, which is dominant in the context of different motivational invariants of Sandzhi Balykov's works, as well as special monographic studies on the writer's literary works. At the same time, in Sandzhi Balykov's writings the issue of expressing everyday details, of realities of everyday life of Kalmyks as a part of an ethnosocial group localized in time and space, representing the Don Cossack culture, requires special attention.

\section{Discussion}

It happened historically that the part of Kalmyks who came to the Don in the XVIIth century settled in those places joining Don Cossack troops. Such factors as accedence to the Cossacks, a sedentary lifestyle had made a beneficial impact on the social situation and by the end of the XIXth - the early XXth centuries Don Kalmyks stood out from the rest of Kalmyks for a significant number of ethnic clerisy and the Buddhist clergy. At that time there were 13 Kalmyk Cossack villages in the Don Army Region, the male population of which except for highly positioned clergy representatives were obligatorily called for a draft in Cossack troops.

Cossack mode of life is considered to be a unique and specific environment where military, nomadic, religious and philosophical attitude to life are closely intertwined. Consequently, for some writers mode of life becomes a specific life sphere, a facet of a person's test in which everyday life is often associated with "existence", and acute issues of time are suddenly revealed behind simple down-to-earth problems (Ivanov, 2014). The problem of national identity is combined with the concepts of national stereotype, ethno-, auto- and heteroimages (Srukova et al, 2019).

In S. Balykov's writings the world of the Kalmyk Cossacks is expressed through the image of the steppe before the Civil War: «Змейкой среброчешуйчатой лениво ползет извилистый Сал по калмыцкой степи. Сухое дыханье астраханских песков увлажняет здесь река. Сонно и безмятежно, по вековым тропам течет жизнь в Калмыцкой степи». (The winding Sal is lazily crawling like a snake with silver scale across the Kalmyk steppe. The dry breath of Astrakhan sands is moistened by the river here. Life in the Kalmyk steppe is flowing along centuries-old paths drowsily and serenely) (Balykov, 2013).

A special zest and solemnity is conveyed through the religious world view of the Don Kalmyks-Cossacks: «Геген в калмыцкой станице - большое праздничное событие, на много десятков верст в окружности. В этот день в ту станицу, где происходит общенародное молебствие, под руководством хурульного духовенства, съезжается множество народа из ближних и дальних станиц, со всех степных кошар». (Gegen in the Kalmyk village is a great festive event for many dozens of miles around. On that day a lot of people from near and distant villages, from all the steppe lambing barns come to the village where the national litany takes place directed by the khurul clergy) (Balykov, 2013).

The spatial centre in the novel "Zalamdzha" is a house and a farm of an old Kalmyk horse-breeder that are located above the spacious flooded estuary which had formed a deep curve of the river Sal. Judging by the signs outlined by the author, the economic situation on the farm is rather successful: «Жизнь в кошаре уже кипит утренней суетой: в конюшнях идет уборка упряжных, ездовых и ремонтных лошадей, в базу доят коров, птичница, рассыпая из передника корм, громко созывает разбредающихся птиц, а старый ключник Азван, гремя огромной связкой больших ключей, отворяет двери складов, погребов и амбаров, выдавая кухаркам трех кухонь - белой, черной и хозяйской - дневные продукты» (Life in the lambing barn is humming in the morning bustle: the stables for hackneys, riding horses and remounts are 
being cleaned, cows are being milked in the farmyard, a poultry woman scattering food from her apron is loudly calling wandering birds together, and an old key-keeper Azvan rattling a huge bunch of keys is opening the doors of warehouses, cellars and barns giving out daily products to kitchen maids of three kitchens - white, black and master's ones) (Balykov, 2013).

In connection with traditional folk beliefs house is identified with family and hearth: «Семья у Адучова маленькая: он, жена и дочь Заламджа, от первой покойной жены» (Adychov's family is small: he, his wife and his deceased first wife's daughter Zalamdzha) (Balykov, 2013).

Illustrating everyday routine the author focuses on a generalized description of household life where the religious aspect plays an important role: «Жена, наполнив комнату тибетским благовонным куреньем, сидит, подпоясанная голубым кушаком, перед божницей за утренней молитвой и крутит расписанный тибетскими буквами серебряный молитвенный барабан - 'курде'» (Having filled the room with Tibetan incense smoking, his wife encircled with a blue girdle is sitting in front of an image case for matins winding a silver prayer wheel ornamented with Tibetan letters - kyurde).

A special emphasis in the work is laid to the tradition of a common family feast. It should be noted that much attention is paid to a balanced nutrition with the use of fresh and various food stuff: «Малочисленность семьи тяготит Шавеля, и он любит, чтобы за столом была вся семья. Стол у Адучова обильный и сытный. Порядок еды у него свой: главная еда у Адучова утром, обед несколько легче, а ужин совсем легкий. Поэтому на утреннем столе у Шавеля подают все - и холодную жареную птицу, и горячую яичницу с копченой свининой, и жареного в сметане сазана, и нарезанную баранину в горячем бульоне с луком, и холодных речных раков, чай калмыцкий, весь в каймачных рванцах и пахнущий мускатом, чай русский, кофе, сливки, домашнее печенье.

За густо и обильно уставленным утренним столом, каждый член семьи ест то, что ему понравится. Хозяйка неизменно начинает с чашки калмыцкого чая с кручеными борцыками. Заламджа пьет кофе со сливками и печеньем. А Шавель любит выпить натощак большую рюмку белоголовой водки, закусив парой холодных раков, а потом уже переходит к баранине с луком в бульоне». (Small number of family members weighs on Shavel as he loves to have the whole family at the table. Aduchov's table is hearty and nutritious. He has his own order of food: he has his main meal in the morning, his lunch is much lighter, and the dinner is very light. Therefore everything is served on the morning table - cold fried bird, hot fried eggs with smoke-dried pork and fried in sour cream carp, and chopped mutton in hot broth with onions, and cold crayfish, Kalmyk tea smelling with nutmeg, Russian tea, coffee, cream and homemade cookies.

Sitting at the densely and plentifully laid morning table each family member eats what he/she likes. The hostess invariably begins with a cup of Kalmyk tea with twisted bortsoks. Zalamdzha drinks white coffee with cookies. And Shavel likes to lower a big glass of whiteheaded vodka on an empty stomach, biting after a couple of cold crayfish and then goes on to a lamb with onions in the broth) (Balykov, 2013).

Without doubt, the motive of the economic work of the Don Kalmyks is related to the traditional way of life of nomads, from the earliest times engaged in cattle breeding, represented in S. Balykov's writings as key branches of animal husbandry: «Первым долгом он заезжает к чабанам. Он любит посмотреть, как пятитысячная отара овец, белой полстью принакрыв долину, мирно пасется под наблюдением неподвижных чабанов с длинными «герлыгами» за плечами.

Довольный, что подразнил ревнивого овцевода, Шавель едет на табунный отвод, где тысячный табун доских коней, разбившись на десятки косяков, оберегаемых гарцующими жеребцами, разбрелись по самому тучному пастбищу. 
После табуна Шавель едет к гуртовщикам, проезжает мимо хлебов, осматривает скирды сена, половы и соломы, разбросанные по участку вокруг колодцев» (First things first he calls on shepherds. He likes to watch a five-thousand herd of sheep, having covered the valley with white bedding, peacefully grazing under the supervision of motionless shepherds with big "gerlygs" behind them.

Satisfied with having teased the jealous sheep breeder, Shavel goes to herd branch where the herd of thousand Don horses, breaking into dozens of shoals, guarded by prancing stallions scattered across the most fat pasture.

After the herd Shavel goes to cattle drovers, drives past wheats, examines hey, chaff and straw stacks scattered around the wells) (Balykov, 2013).

The author draws a kind of parallel between ordinary life realities and military service reflecting the essence of the Cossack attitude who should be at any moment ready to pull away from peaceful life and enter the fight with enemy (Ivanov 2014, 242). Thus in S. Balykov's work a traditional motive of the Cossack service is manifested: «-Ну, сынок, да будет тебе на счастье твой конь, - несколько торжественно начал Шавель, подходя к Данзану. - Служи и, с конем твоим, живым здоровым возвращайся на землю, где ты родился, и к рекам, водою которых тебя обмыввали...» (- Well, son, let your horse be your luck, - Shavel began somewhat solemnly approaching Danzan. - Serve and with this horse return safe and sound to the land where you were born, to the rivers in the waters of which you were washed...) (Balykov, 2013).

This way, through the motives of habitual Cossack mode of life, S. Balykov's writings demonstrate a tragic history of many people, the whole country and biography of several generations - the First World War, the Civil War, the first wave of Russian emigration, etc.: « пошла гулять по калмыцким возам смерть. Гибли люди от голода, холода, косили богатую жатву болезни. Догоняли калмыков и резали, насиловали большевики, грабили зеленые, обижали белые... Мир, перед которым калмыцкие представители у власти решили 'демонстрировать всенародный характер антибольшевистской борьбы', со дня своего сотворения не видел подобных ужасов в жизни одного народа, но он не интересовался этой демонстрацией» (And death started wandering around Kalmyk carts. People died from hunger, cold and diseases mowed rich harvests. The Kalmyks were caught up, cut and raped by the Bolsheviks, robbed by the green, and offended by the white. The world before which the Kalmyk authorities decided to 'demonstrate the nationwide character of anti-Bolsheviks' struggle' since the day of its creation has not seen such horrors in the life of one ethnic group, that wasn't interested in such a demonstration) (Balykov, 2013).

Sandzhi Balykov who went through the Civil War, and then found himself in the first wave of emigration, has not seen the wide Zadonian steppe any longer, but he conveyed all his deepest feelings - pain for his fellow-countrymen, yearning for his native land, fidelity to the Cossacks' tradition through autobiographical motives that were close and understandable to his lyrical hero in the novel "Zalamdzha": «Множество калмыков вернулось за это время домой, под разбойную власть коммунистов, и многие из них поплатились за свое доверие подлой власти, муками голода, умерев в снегах севера. Наиболее стойкие и непокорные духом обрекли себя на дальнейшие чужбинные годы» (Lots of Kalmyks returned home during this period of time under the robbery Communists' authorities, and many of them paid for their trust to dishonourable regime with torments of hunger, with their lives in southern snows. The most hardy and rebellious doomed themselves for further years in alien lands) (Balykov, 2013). 


\section{Results}

Summing up, the realities of the national mode of life and the foundations of Kalmyk Cossacks are fully reflected in the writer's works. The consideration of preceding events having made an impact on the writer's works and his interaction with common-literary process gives us reasons to presume the extreme importance of historical cultural phenomena, the reflection of which has become the result of S. Balykov's immediate flashbacks.

Undoubtedly, in the artistic consciousness and writings of S. Balykov the Cossacks existed as a social phenomenon and a type of mentality. The actual life of Cossacks, the richest Cossack cultural tradition with its particular spatial symbolism and specific content, due to the author's unschooled talent and breadth of his political views are closely intertwined with fates of the main characters of the novel "Zalamdzha" and reflect the tragedy of Kalmyk people and the whole country.

\section{Conclusions}

Summing up, the history of national literature is based, first of all, on the recognition of the dialectical unity of national and international historical and literary processes from the point of view of general literary and historical laws. Based on the specifics of individual writers and their works, the patterns of the corresponding national literature or group of literatures are clarified. Without the continuity of generations and the productive assimilation of the spiritual values created by predecessors, the development of the history and culture of the people is impossible. Prospects for further research are presented in the study of the stage of formation and formation of Kalmyk literature, directly related to the literary activity of the Kalmyk emigration in 19201940. Determining the specifics of the artistic world of the emigrant writer Sanji Balykov through the prism of the national, everyday and socio-historical development of society of that era is an interesting and meaningful problem that requires further reflection.

\section{References}

Alekseeva, P.E. (1995). Far from the motherland. Teegin gerl, 8, pp. 75-80.

Alekseeva, P.E. (2006). Sandzhi Balykov is an outstanding representative of the Kalmyk abroad. Teegin gerl. 1, pp. 65-74.

Alekseeva, P.E. (2010). People and fates. Elista: APP “Dzhangar".

Balinov, Sn.N. (1976). Foreword. In Balykov S.B. Stronger than power (10-14): Munich.

Balykov, S.B. (2013). Zalamdzha. M.: Memorial-Museum "The Don Cossacks in the fight against the Bolsheviks".

Basangova, T.G. (2015). Ceremonies and ritual folklore of Kalmyks in the novel of S.Balykov "The maiden's honour". Proceedings from the III International Forum "Idel-Altai: history and traditional culture of Eurasean peoples". Gorno-Altaisk: Gorno-Altaisk typography.

Bayanova, A.T. (2013). Kalmyk emigre publications in the book culture of Kalmyks. Language and culture, 8, pp. 15-19.

Bicheev, B.A. (1991). The influence of written monuments and folklore on the development of Kalmyk literature (20-30 ${ }^{\text {th }}$ years): abstract of a thesis cand. philol. Moscow.

Bormanzhinov, A. (1998). Notes of the Kalmyk Diaspora. Teegin gerl, 6, pp. 65-69.

Bormanzhinov, A. (2004). Sandzhi Balykov. Teegin gerl, 4, pp. 65-69. 
Burykin, A.A. (2006). Don dialectisms and South Russian vocabulary in the language of Russian prose of the Kalmyk writer Sandzhi Balykov. Way to the native word. Collection of scientific articles on the $60^{\text {th }}$ anniversary of Professor R.P.Kudryavtsev. Volgograd: Publishing house of VSPU.

Dzhambinova, R.A. (2003). The research criterion is scientific ethics. In Kalmyk Literature: problems of development (150-161). Elista: APP "Dzhangar".

Gilfanova, G., Valeeva, A., \& Nikulina, E. (2020). The German Novel of the 1960-70s: Artistic Conception of History. Amazonia Investiga, 9(26), 554-557. https://amazoniainvestiga.info/index.php/amazonia/article/view/1187/1076 https://doi.org/10.34069/AI/2020.26.02.62

Goryaev, A.T. \& Borisenko, I.V. (1998). Essays on the history of Kalmyk emigration. Elista: APP "Dzhangar".

Guchinova, E-B.M. (2004). Kalmyk Road street: history, culture and identity in the Kalmyk community. St.P.: Aleteya.

Ivanov, K.G. (2014). The motive of the Cossack life in the works of N. Turoverov. Bulletin of Bryansk State University, 2, pp. 242-249.

Kondratjeva, V.V. \& Larionova, M.Ch. (2015). Cossack theme in the works of A.P. Chekhov: the story "Pecheneg". Bulletin of Volgograd State Pedagogical University, 6 (101), pp. $159-162$.

Larionova, M.Ch. (2018). Don Cossacks in the works of A.P. Chekhov. Ural Historical Bulletin, 2(59), pp. 87-93.

Ochirova, N.G. (2019). The regional features of the emergence of public associations in Russia and the main directions of their activity (on the example of the Republic of Kalmykia). Bulletin of the Volgograd State University. Series 4: History. Regional Studies. International Relations, 24(4), pp. 191-201.

Sharmandzhiev, D.A. (2013). From the history of the Kalmyk emigration of the XXth century to European countries and the USA. Ethnographic review, 3, pp. 117-124.

Srukova, Y., Naptsok, B., Unarokova, R., Sokolova, G., \& Kudaeva, Z. (2019). Peculiarities of national identity in Alim Keshokov's novel "Saber for the Emir". Amazonia Investiga, 8(24), 402-413. Retrieved from https://amazoniainvestiga.info/index.php/amazonia/article/view/1000

Topalova, D. Yu. (2015). National originality of S. Balykov's stories "Trampled tulip", "Near the invisible wall”. Bulletin of KIGI RAS, 4, pp. 161-166. 